\title{
Managing service quality customer loyalty and the role of relationship length
}

\author{
Naveed Ahmad ${ }^{1, *}$, Nadeem Iqbal ${ }^{2}$, Mansoor Ahmad ${ }^{3}$ \\ ${ }^{1}$ Faculty of Management Sciences, Indus International Institute, D. G. Khan, Pakistan \\ ${ }^{2}$ Faculty of Management Sciences, Ghazi University, D. G. Khan, Pakistan \\ ${ }^{3}$ Department of Business Administration, Air University, Multan Campus, Pakistan \\ *E-mail address: naveeddgk2010@gmail.com
}

\begin{abstract}
The purpose of this paper is to investigate the management of service quality, customer loyalty and the role of relationship length in Islamic and conventional banks. Data was collected from two sectors i.e. Islamic banks and Conventional Banks within four cities of Pakistan and the questionnaires were distributed accordingly. Sample size of 400 was taken as a whole accounts 100 from Islamabad, 100 Lahore, 100 Multan and Faisal Abad each from both sectors. Regression and factor analysis of all variables were executed. $\mathrm{T}$, test is applied on both sectors Islamic and conventional banks for comparisons. Results show that brand awareness has no impact on corporate image. Innovation capability has a significant impact to attract the customer towards the organization and Customer service quality is highly significant on corporate image. Customer service quality is highly significant on switching cost.
\end{abstract}

Keywords: Service Quality; Customer Loyalty; Banks, Relationship length; switching cost

\section{INTRODUCTION}

The set of earnings delivered from the service provider to the service consumer. It is reported that services have four characteristics that make unlike it from goods i.e. intangibility, perish ability, inseparability and heterogeneity. Service quality is a multidimensional thought that varies in meanings among researchers. The Banks in Pakistan have realized the significance of service quality to boost their operations and assortment. It is said that service advantage leads to consumer happiness in every sector of the Pakistani banking atmosphere (Jamal \& Naser, 2002).

Most banks are competing for more customers like conventional and Islamic banks in Pakistan. It is an achievement of agreeable a want, need, require of prospect. Customer satisfaction is significant due to an enlarged opposition in banking division. It is clear that customer increase the position of the bank in the service surroundings. When customer complaints are healthy solved and the familiarity fixed between the firm and the customer, this is the best way of customer satisfaction, trust and promise to the firm. Now what is faithfulness? Customer loyalty is precarious activities promotion in today's insistent surroundings. Faithfulness refers to a harshly held assure to purchase a preferred product or service again and again in the expectations. 
Switching costs theoretical monetary and emotional costs changing from one option to another. Stability costs contain the size and chance of lost performance benefits. Many organizations are difficult to calculate the superiority of their services and believe the transactions between service superiority and purchaser fulfillment. What is service? Many studies inspect of publicity have to define service quality and make bigger instruments to calculate it. Many studies have used SERVQUAL to estimate service quality in a variety of domains, ranging from financial services (Lin \& Wei, 1999), service of physical condition service of travel agent (Kaynama \& Black, 2000), and service of retailing (Mehta, 2000), restaurants (Lee \& Hing, 1995).

The major purpose of this study is to look into the worth and capability of service in measuring service quality and its association to purchaser fulfillment. There is visible want that all companies today increase the modernism capacity to compete the competitive market, and a serious question is how increase in innovation capability can be brought about? First, how can the present state of modernism potential be known, and secondly, what desire to be bring out to increase pioneering presentation?

These were the helping questions at the back of this research. The basis following the company's sensitive interest in assessing and promoting improvement ability is that the idea of modernization and good environment in organization. The company has a well-built history of knowledge development, urban in service marketplace, but has recently located themselves as a provider of solutions, counting goods knowledge and services. Such activity implies that companies want to pick up their potential to enlarge and present product and service scheme solutions (Baines et al., 2007).

Customer faith levels of individuality, such as, ability, customization, constancy, speed, Provided that customers with supplier heterogeneity, product difficulty, and superior assessment is one way of rising switching costs and building way out barriers. The difference, in association, a customer may have need of information about a firm more particularly, It is hard for new customers to base their performance on their incomplete accepting of basis, they may allow the latter's obvious corporate representation to establish the level of undertake they place in the service's trustworthiness and superiority. Therefore, early stages of a supplier relationship, customers may know switching costs based on helpful corporate image. In short switching cost, corporate image and response process or ultimately consequence on customer loyalty because loyalty represent deep commitment of customer with organization and repurchase decision.

The study is important to identify why customer switch to other brand? The significance of study determined customer switch to other brand when firm not focus on customers need and demand and have no any idea to solve the customer's problems. The study will help service providers' how better they can response to customers during service delivery, how they can improve their services, how friendly and relaxed environment can be created for customers, how customer imagine their service performance input by the company? Can this service is beneficial for customer? Is customer satisfied? When these all things are completed and then customer becomes loyal. The participating in new service growth difficult, evaluating publicity campaigns, generous opinions on service quality, create modernism and distribution insight about displeased customer needs. 


\section{LITERATURE REVIEW}

\section{1. Customer Satisfaction}

It is the best understanding the description of the expression of purchaser happiness, (Mehta, 2000). The appearance does not simply communicate a happy customer, but slightly various than that. Buyer happiness is certainty expression most generally used in the business and introduces modern. The trade expression details concerning a number of the kind of goods and services provided by company to rally its buyer's trust. In a ready for action market where trade effort for clients, buyer pleasure is seen a differentiator and more and more has become a key part of production policy. A worldwide subject that affects all firms, anyway of its size, whether earnings or non-profit, local or global. Transaction-specific approval is the customer's very individual approximation of their considerate and response towards a exacting service meet (Cronin Jr \& Taylor, 1992)

\section{1. 1. Customer Satisfaction in Retail Banking}

Consumer satisfaction and services quality are equally reliable. The positive service quality, give good purchaser approval. In banking division, there is no familiar typical balance to calculate the professed quality of bank service. Thus, ready for action lead during important service, quality is more significant join to stay alive with bank. Measuring service quality seems to false difficulty to service providers since of the single independence of military: intangibility, heterogeneity, inseparability and perish ability.

\section{1. 2. Satisfaction And Loyalty}

Loyalty and satisfaction are linked, because satisfaction increases loyalty. Those who are not trusted customer in marketplace are not possible to be loyal. In business-to business setting, and generate actually controlling goods for reliability faith on connection strength hope. He argued that this was businesses base their pay for marketing result on performance issues.

\section{2. Switching Cost}

The costs caught up in changing from one dealer to different (Heide \& Weiss, 1995). In addition, this section includes the defeat of faithfulness payback incurred by firm when a purchaser takes their response in different position (Heide \& Weiss, 1995). Designed for instance, customer information with a provider's service actions constitutes a type of switching cost, because customer becomes to an end the relationship. Earlier studies have created a concept of customer value in two scopes: "provide" and "acquire" (Heskett \& Schlesinger, 1994). The "provide" size includes expenses such as moment, search expenses, and material attempt in employment in overpowering of service. Based on these, concludes that financial charge of relational and aspects of service are equally suitable a strong optimistic ability on switching cost, and thus hand round as barriers to mode out. Because during the purchase of service customers face more and high cost when switch to another new supplier. Thus, as switching costs increase with the passage of time that is more significant thing in customer repurchase decision (Liu et al., 2005).

\section{3. Interrelationship of Customer Value, Corporate Image And Switching Cost}

Customer evaluation of service supplier communications becomes more important in long term associations. This will create superior switching costs (Aydin and Ozer, 2005). 
The outstanding services may consequence from customer knowledge to the above mentioned offer-related uniqueness. The course of relationship, customers become more familiar with their service provider. The threat exists obviously inside the service production, because service excellence cannot be evaluated in the pre-purchase stage (Sharma et al., 1997). The corporate image and customer value have strong relationship with each other. In near the beginning stages of supplier relationship, consumers may know switching cost based on positive profitable image.

\section{4. Service Quality}

There is no any hesitation; service quality is very significant part in any business connected movement. A client's judgment of service quality and the follow-on point of fulfillment are apparent to engage base line measures of business success.

According to the service quality theory (Oliver, 1980), it is predicted that consumers will moderator that quality as low and their demands are not on their expectation about quality of service then they switch the brand. According to (Grönroos, 1984), the given service of perceived quality consequence of assessment procedure because clients often make estimate between the prepared services the global paper of change, organization and expertise, imagine with perception of the services that they achieve.

He finished that the excellence of service is need on two variables: Predictable service and apparent service. Quality spells power or excellence (Taylor \& Todd, 1995). Service quality has been generally documented and practical in a variety of services location for diversity of industries in history decade.

Examples include: physical condition care location, dental school enduring clinic, business school post centre, tire stock up, actual care hospital, large sell chains, banking, bother administer, dried out assault, and fast food restaurants (Bitner et al., 1994: Brown et al., 1985; Cronin Jr \& Taylor, 1992, 1994;).

The dissatisfaction established connecting to Service quality measuring device might have more significant study theme since of its clear relationship to expenses profitability (Bitner, 1990, 1992; Rust et al., 1995;), customer satisfaction (Bitner, 1990; Brown, W. Brown et al., 1996) customer retention (Sharma \& Patterson, 2000), and positive word of mouth.

\section{5. Innovation Capability}

An organization's competence to arrange its physical and slight assets, to achieve the task or to fetch out actions in the firm (Maritan, 2001). Still, according to Vargo, (2007), "capabilities are compound bundles of skills and accumulated awareness, exercised through decision-making processes that allow firms to organize behavior and create use of their possessions". Whereas capabilities are also branded as individual ability and the connect set that distinguishes and provides advantage. From the above definitions, organizational capabilities are those that are not simple to duplicate by other competitors that have claim for exploit benefit and marketing presentation (Eggert \& Ulaga, 2002).

\section{6. Corporate Image}

The overall indication through on the free mind about a firm (Barich \& Kotler, 1991). Corporate image can be flexible occurrence. Some accurate groups may hold a variety of different images of private firm, as a consequence of their separate experiences and associates with the corporation (Dowling, 1993). 
Marketable representation is associated the objective and behavioral approach of a firm, such as industry name, structural mean, concoction of products and services on hand, and communications (Nguyen \& Leblanc, 2001).

Company reflection is follow-on from progress stemming from thoughts, attitude, and use experiences connected to selling that are retrieve from memories loose into mentality images (Lin \& Wei, 1999). Existing research has established that service transactions develop from end to end precise service encounters (Heide \& Weiss, 1995), The earlier supplier association, customers are often confronted without significant what they look ahead from the service and image.

Exceptional the intangibility issue, customer frequently well-known with risky service and consequence need to gain single statement in examine source before opening relationship. The early service meet, customers will search in move in front or information, of service quality. The opening phases of association, customers rely above all on the provider's supposed reliability; introduction word in the promptness and excellence of the services they distribute in corporation (Garbarino \& Johnson, 1999).

Companies go to build strong relationship with customer by using publicity, product names and additional indication to get better the corporate image. The service provider personally independence to form corporate image, this document advise that corporate image compose a good figure that will produce encouraging word of mouth and strong relationship in the process of customer loyalty.

\section{7. Conceptual framework}

Based on the above-mentioned literature review, the following theoretical model framework has been developed.

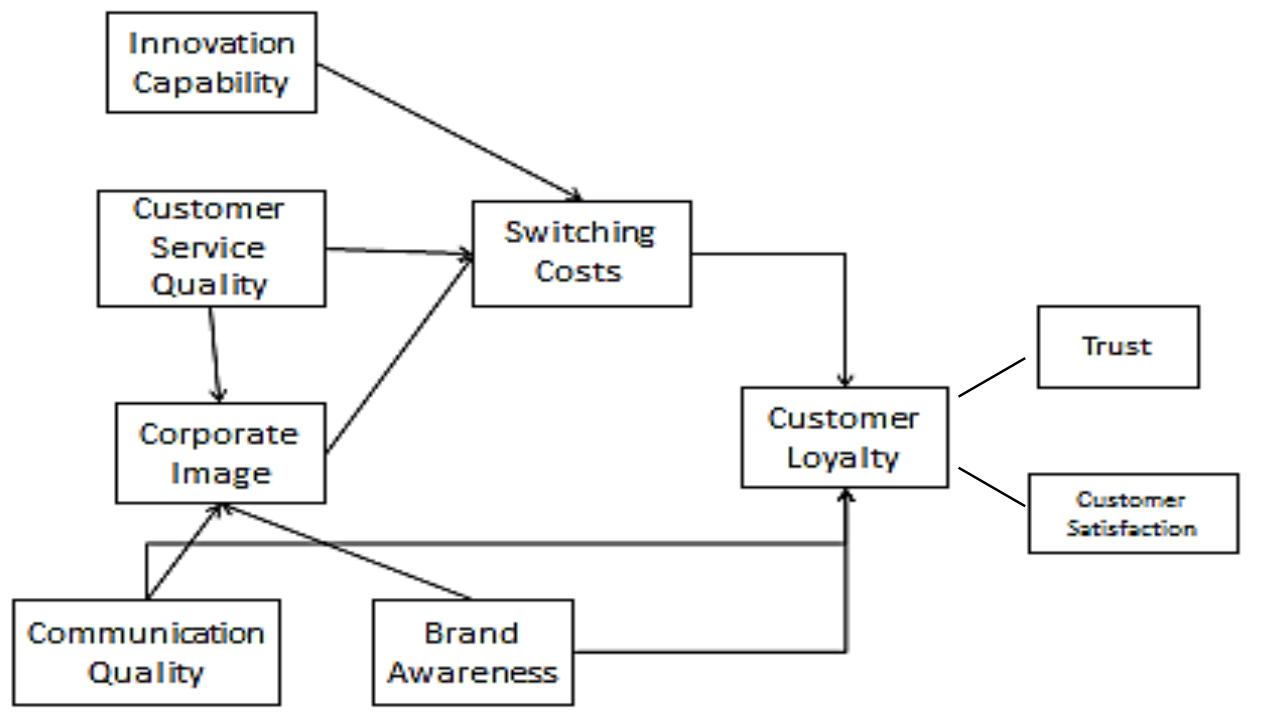

\section{8. Development of Hypothesis}

H1 Customer service quality positively influences switching costs

H2 Innovation capability has relationship with switching costs. 
H3 Corporate image has positive effect on switching costs.

H4 Customer service quality has impact on corporate image.

H5 Communication quality has positive effect on corporate image..

H6 Brand awareness has positive effect on corporate image.

H7 Switching costs have impact on customer loyalty.

H8 Communication quality has positively effect on corporate loyalty

H9 Brand awareness has positively effect on corporate loyalty.

\section{METHODOLOGY}

Data was collected from two sectors i.e. Islamic bank and Conventional Bank and form four cities of Pakistan and the questionnaires were distributed accordingly. Sample size of 400 was taken as a whole accounts 100 from Islamabad, 100 Lahore, 100 Multan and Faisal Abad each from both sectors. The sample size was taken from these cities equally from both sectors. Structured self-administrated questionnaire was developed for taking response of population. Questions were designed on five scale starting from strongly agrees, agree, natural disagree to strongly disagree. In data analysis tools and techniques the structural model equation was used that according to model and factor analysis of all variable were founded. The T, TEST is applied on both sectors Islamic and conventional banks for comparisons.

\section{1. Sampling Technique}

This research is based on sector wise study of population of Islamic and Conventional Banking. Systematic sampling technique is being used for data collection. Every fifth customer who visits banks services was asked to respond. These are the customers who frequently visit their service providers for any complain, information, or to purchase service of these service firms. These are the customers who interact with their service provider without being afraid. And they want to continue their dealing with their service provider in case of accurate complaint handling by the staff.

Table 1. Sample size.

\begin{tabular}{|c|c|c|c|c|}
\hline & City & $\begin{array}{c}\text { No. of } \\
\text { respondents }\end{array}$ & Islamic bank & $\begin{array}{c}\text { Conventional } \\
\text { Bank }\end{array}$ \\
\hline 1 & Islamabad & 100 & 50 & 50 \\
\hline 2 & Faisal Abad & 100 & 50 & 50 \\
\hline 3 & Lahore & 100 & 50 & 50 \\
\hline 4 & Multan & 100 & 50 & 50 \\
\hline & Total & 400 & 200 & 200 \\
\hline
\end{tabular}




\section{RESULT AND DISCUSSION}

In factor analysis first column shows the value of communication quality, second column shows the values of brand awareness and in third column shows the values of customer service quality. Further fourth and fifth, sixth column shows the values of switching cost, corporate image and innovation capability respectively.

Table 2. Factor Analysis.

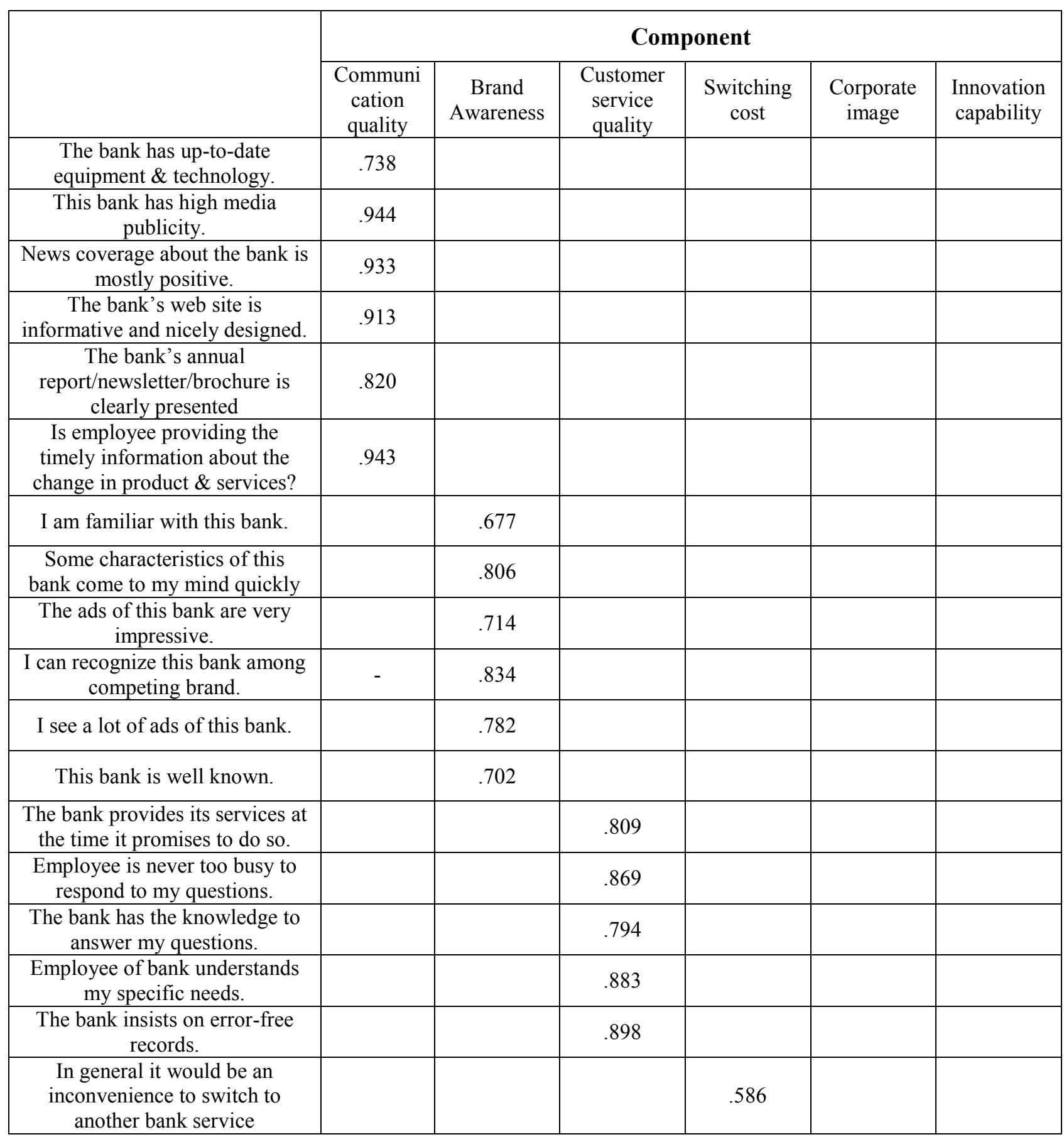




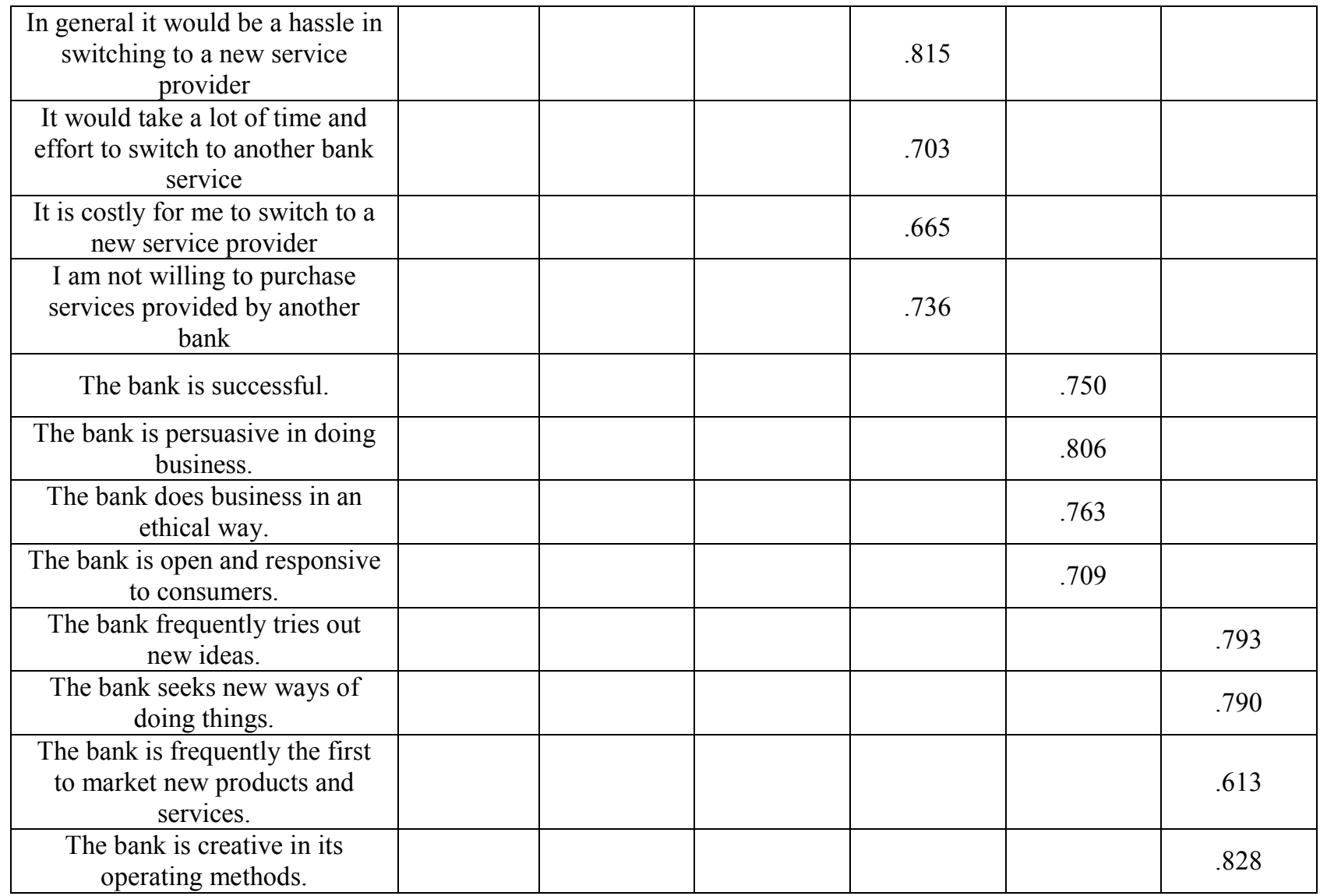

\section{1. Structural model equation}

Table 3. Model Fit.

\begin{tabular}{|c|c|c|}
\hline Fitness Index & Required value & Results \\
\hline CHI SQUARE P VALUE & $>0.05$ & .000 \\
\hline CMIN/DF & $2.00-5.00$ & 4.19 \\
\hline GFI & $>0.90$ & .980 \\
\hline AGFI & $>0.90$ & .910 \\
\hline RMSE & $<0.08$ & .089 \\
\hline RMR & $<0.08$ & .021 \\
\hline IFI & $>0.90$ & .943 \\
\hline NFI & $>0.90$ & .927 \\
\hline CFI & $>0.90$ & .941 \\
\hline NNFI & $>0.90$ & .793 \\
\hline
\end{tabular}

The model fit results show that the model is above good fit. 


\section{2. Regression}

Table 4. Regression Weights.

\begin{tabular}{|c|c|c|c|c|c|c|}
\hline & & & Estimate & S.E. & C.R. & P \\
\hline CI & $<---$ & Communication quality & .094 & .045 & 2.090 & .037 \\
\hline CI & $<---$ & Brand awareness & .079 & .047 & 1.676 & .094 \\
\hline CI & $<---$ & Customer service quality & .239 & .049 & 4.863 & $* * *$ \\
\hline SC & $<---$ & Innovation quality & .162 & .055 & 2.967 & .003 \\
\hline SC & $<---$ & Customer service quality & .415 & .046 & 8.947 & $* * *$ \\
\hline SC & $<---$ & Corporate image & .202 & .047 & 4.272 & $* * *$ \\
\hline CS & $<---$ & Switching cost & .044 & .040 & 1.102 & .270 \\
\hline Trust & $<---$ & Switching cost & .034 & .037 & .943 & .346 \\
\hline CS & $<---$ & Brand awareness & .279 & .040 & 6.975 & $* * *$ \\
\hline Trust & $<---$ & Communication quality & .195 & .031 & 6.205 & $* * *$ \\
\hline Trust & $<---$ & Brand awareness & .195 & .034 & 5.749 & $* * *$ \\
\hline Trust & $<---$ & Customer service quality & .119 & .038 & 3.098 & .002 \\
\hline CS & $<---$ & Innovation capability & .172 & .049 & 3.518 & $* * *$ \\
\hline
\end{tabular}

Regression analysis results show that brand awareness has no impact on corporate image. Innovation capability has a significant impact to attract the customer towards the organization and Customer service quality is highly significant on corporate image. Customer service quality is highly significant on switching cost. The hypothesis $3 \mathrm{~b}$ which shows the relationship between corporate image and switching cost, the results shows that corporate image is highly significant on switching cost. Brand awareness is highly significant on customer satisfaction. Communication quality is highly significant on trust. Brand awareness is highly significant on trust. Innovation capability is significant on switching cost. Communication quality is significant on corporate image and innovation capability on switching costs $p<.005$ and customer service quality $\mathrm{p}<.005$ is significant on trust.

The results found that customer service quality is mire significant on switching costs and brand awareness and corporate image. Furthermore if corporate have positive communication quality then image of organization become positive and customer become loyal. Discussion directs that customer-perceived value, corporate image, and switching costs are important determinants of loyalty. The impact of corporate image on customer loyalty is sensitive when customers have used a service provider for long period .Even the study has indicated that corporate image affects consumer actions and perception of a company's product quality and dependability. 
The findings of this study show that customer loyalty depends on the awareness of brand in customer's mind and there should be new technology new idea like innovation of product and image of corporate becomes the source of loyalty. Breakdown to incorporate unexpected occasion transactions is possible the role played by length of relationship in the customer conservation process. Moreover, breakdown in switching costs is possible result in the undervaluation of the mediating role played by switching costs in the customer retention process.

\section{CONCLUSIONS AND MANAGERIAL IMPLICATIONS}

Many studies have emphasized the need to expand suitable and dependable measures of the loyalty through service quality. Most of them have made many labors to apply SERVQUAL, a normal method used to measure the service quality, they have introduced the SERVQUAL, and examined that it has superior collision on loyalty. Since many banks use online business through internet to intact with their business partners and customer in internet business area. We introduced the method of SERVQUAL tool for banking and check customer loyalty. Customer loyalty depends on these variables: Switching cost, brand awareness Innovation capability, perceived value, communication quality trust and satisfaction. In these variable the most common variables which satisfied the customer is SERVQUAL, which is more important for customer retention, In the investigative and affirmative factor analysis, our study elective a four-factor model of SERVQUAL including Tangibles, Reliability, Responsiveness, and Empathy. In addition, we look at the relationships in the midst of customer satisfaction, customer retention, and service quality. This study reveals that SERVQUAL is appropriate device for measuring the quality of online banking services. This study examined both Islamic and conventional bank on basis of customer loyalty, the results from the present study propose several implications for the use of SERVQUAL in the term of loyalty in banking area. This study further defines that corporate image has positive effect on switching cost and customer loyalty. Customer loyalty depends on trust and satisfaction. Another executive proposition is that satisfaction is a strong analyst of customer loyalty, even though there are existing factors, like switching costs. Further innovation capability and customer service quality measure the perceived quality. Therefore, managers in the banking setting are supposed to watch the growth of satisfaction level among their clients and customer.

\section{LIMITATIONS AND FUTURE RESEARCH DIRECTIONS}

The collection of data one type not gives the positive result. Loyalty, the present study listening with awareness on customer value and corporate image. The length of relationship have great impact on company image the firm should be stables it. In this study, the sample structure should be in possible counting. As mentioned above, one year is deemed a fitting location period for shorter- and longer-term relationships, as conventional bank and Islamic bank provide a good services with their frequency. The relationship of one group is less or more than one years and group second relationship is three years or less than three years. Future research may look upon as increasing the sample size for better comparison between groups. Finally, a cross-sectional research plan does not present the same insight into the dynamics of customer relationships within a firm, compared with that of a proper design. 


\section{References}

[1] Aydin S., Özer G., European Journal of marketing 39(7/8) (2005) 910-925.

[2] Baines T., Lightfoot H. W., Evans S., Neely A., Greenough R., Peppard J., Tiwari A., Proceedings of the Institution of Mechanical Engineers, Part B: Journal of Engineering Manufacture 221(10) (2007) 1543-1552.

[3] Barich H., Kotler P., Sloan management review 32(2) (1991) 94.

[4] Bitner M. J., The Journal of Marketing (1990) 69-82.

[5] Bitner M. J., Journal of marketing 56(2) (1992).

[6] Bitner M. J., Booms B. H., Mohr L. A., Journal of marketing 58(4) (1994).

[7] Brown S. W., Cowles D. L., Tuten T. L., International Journal of Service Industry Management 7(5) (1996) 32-46.

[8] Brown T. J., Churchill G.A., Peter J.P., Journal of Retailing 69(1) (1985) 127-139.

[9] Cronin Jr J. J., Taylor S. A., The journal of marketing (1992) 55-68.

[10] Cronin Jr J. J., Taylor S. A., Journal of marketing 58(1) (1994).

[11] Davies G., Chun R., da Silva R. V., Roper S., Corporate Reputation Review 7(2) (2004) 125-146.

[12] Dowling G. R., Long range planning 26(2) (1993) 101-109.

[13] Eggert A., Ulaga W., Journal of Business \& industrial marketing 17(2/3) (2002) 107-118.

[14] Garbarino E., Johnson M. S., The Journal of Marketing (1999) 70-87.

[15] Grönroos C., European Journal of marketing 18(4) (1984) 36-44.

[16] Heide J. B., Weiss A. M., The Journal of Marketing (1995) 30-43.

[17] Heskett J. L., Schlesinger L., Harvard business review 72(2) (1994) 164-174.

[18] Jamal A., Naser K., International Journal of Bank Marketing 20(4) (2002) 146-160.

[19] Kaynama S. A., Black C. I., Journal of Professional Services Marketing 21(1) (2000) 63-88.

[20] Lee Y. L., Hing N., International Journal of Hospitality Management 14(3) (1995) 293-310.

[21] Lin X., Wei B., Journal of Professional Services Marketing 20(1) (1999) 135-146.

[22] Liu A. H., Leach M. P., Bernhardt K. L., Journal of Business Research 58(5) (2005) 559-568.

[23] Maritan C. A., Academy of Management Journal 44(3) (2001) 513-531.

[24] Mehta S. C., Journal of Professional Services Marketing 20(2) (2000) 33.

[25] Nguyen N., Leblanc G., Journal of retailing and Consumer Services 8(4) (2001) 227-236.

[26] Oliver R. L., Journal of marketing research (1980) 460-469. 
[27] Rust R. T., Zahorik A. J., Keiningham T. L., Journal of marketing 59(2) (1995).

[28] Sharma N., Patterson P. G., International Journal of Service Industry Management 11(5) (2000) 470-490.

[29] Tax S. S., Brown S. W., Chandrashekaran M., Journal of marketing 62(2) (1998).

[30] Taylor S., Todd P. A., Information systems research 6(2) (1995) 144-176.

[31] Vargo S. L., Australasian Marketing Journal 15(1) (2007) 53-60.

[32] Nadeem Iqbal, Naveed Ahmad, Zeeshan Riaz, International Letters of Social and Humanistic Sciences 9 (2014) 14-25.

[33] M. Shoukat Malik, Muhammad Nadeem, International Letters of Social and Humanistic Sciences 10(1) (2014) 9-19.

[34] Nadeem Iqbal, Naveed Ahmad, Hafeez Ullah, Aun Abbas, International Letters of Social and Humanistic Sciences 24 (2014) 15-25.

[35] Muhammad Nadeem, Naveed Ahmad, Muhammad Abdullah, Naqvi Hamad, International Letters of Social and Humanistic Sciences 25 (2014) 51-58.

[36] Nadeem Iqbal, Najeeb Haider, Muhammad Ramzan Akhtar, Sumia Hafiz Abdul Karim, International Letters of Social and Humanistic Sciences 26 (2014) 71-81. 